чаще мочиться. Ранка сначала, посль прижиганія, каць будто забухла и больная дня два лежала почти сухая, но потомь qерезъ фистулу опять начала просачиваться моча, но въ меньшемь количествљ, чюмь прежде, и больная могла мочиться отчасти и произвольно черезъ мочеиспускательный каналъ. 22 Нолбря я должна. была уъххать на нъссколько дней на вемское собраніе, больная выписалась, обњщая явиться опять для повторенія прижиганія или, если понадобится, для вашиванія фистулы. Явилась она 29 Декабря. Фистула кругловатой формы, значительно уменьшилась, не пропускаеть и тонкаго пуговчатаго зонда, моча черезь нее просачивается, но мало-по гаплямъ, и то только въ томъ случағ, когда больная долге время воздерживается оть мочеиспусканія, Если же она мочится часто, то ходить совершенно сухая. Своимь положеніемь очень довольна. Въ больницу в'ь настоящее время лечь не можеть по домашнимь обстоятельствамъ; но обњщает лечь позже

\title{
FIBROMYOMA SUBMUCOSUM UTERI. ENUCLEATIO PER VAGINAM.
}

\author{
А-ра Л. И. Соноловснаго,
}

(Долольено въ застіданіи Акушерско-Гинекологич. общества въ Спб. 16 ашрвия 1892 года).

24-го октября 1889 г. ко мнъ явилась больная Прасковья Сергъева А. 46 льъть, по случаю сильнаго гровотеченія, которое у больной очень часто повторяется, уже впродолженіи года.

Больная первыя menstrua получила на 17-мъ году, которыя появлялись чрезъ 3 недтли и продолжались по 4 дня. Рожала 3 раза, посльдніе роды были 12 ль̌ьт тому назадъ.

Въ настоящее время больная въ выспей степени анемичн. Температура у больной $39,8^{\circ} \mathrm{C}$.

При внутреннемъ изсльдованіи, я нашель uterus величиною съ большой апельсинъ. Кровотеченіе очень сильное, запахъ выдтленій изъ vaginae сильно гангренозный. 
Portio vaginalis здорово, сглажено и открыто на монету полтинникъ. Изъ collum uteri выдается сантиметра на три въ полость vaginae нижній отрьзок'ь fibromyomatis sabmucosi uteri, который на поверхности совершенно гангренизовань.

Два пальца свободно проходлть, въ полость uteri, между стظнкой матки и fibromyoma submucosum corporis uteri.

Іри болґе подробномь изсльдованіи оказывается, что слизистая оболочка матки, покрывающал фиброміому, въ нижнемъ ея отрђзкћ, разрушена гангреной и между фиброміомой и сливистой оболочкой (капсулой) можно пройти пальцемъ.

Fibromyoma помыщается въ полости матки выше os internum colli uteri и своимь широкимь основаніемь выходить изь передней и львой стњнги тьла жатки. Величиною fibromyoma съ апельсинъ.

Чрезъ брюшные покровы прощупывается поверхность матки соверпенно гладкая, нъть никакихь возвышеній такь что можно предположить, что fibromyoma submucosum не доходить до перитонеальнаго покрова матки.

Увћреный въ томъ, что можно удалить опухоль въ одинъ пріемъ, я рышился сдњлать enucleatio fibromyom. snbmucosi per vaginam ex tempore.

На операпію эту я смотрьль, какъ на ultimum refugium.

Дезинфицироваль я маточный рукавъ и гангренесцированнуг часть опухолє.

Фикспроваль чрезь брюшные покровы матку и двумл пальцами вошель между капсулой и опухолью, старалсь отдею.лить широкое мъсто прикрђпленія опухоли оть стюенки матки, какь

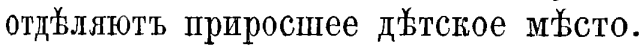

Рыхлая соединительная ткань, между опухолью и стњнкой матки, была очень уступчива. Чрезь брюшные покровы, фиксируя матку, я понстатироваль движенія своихь пальцевь въ полости матки.

Вездњ толщина стьнки матки была достаточна.

Когда часть опухоли была отдылена, то я захватиль опухоль корндангомь и, не извлекая опухоли, чтобы непропзвести inversio uteri, я продолжаль, безь вслкаго насилія, enucleatio in situ.

Кровотеченіе во время вылущенія было не сильное, больная не жаловалась ни на какую боль, и чрезь 1/4 часа мн安 удалось вылущить всю фиброміому, которую я имњю честь теперь представить обществу. 
Діаметр'ь удаленной фиброміомы $=9 \mathrm{ctm}$. Окружность $=21$ ctm.

По извлеченіи опухоли, отдъленная слизистая оболочка (капсула) была удалена ножницами. Вея полость матги и мгъсто пригр‡пленія опухоли были посыпаны іодоформомъ.

Матка тотчась же сократилась, кровотеченіе остановилось. данано деслть гранъ pulv. secal. cornuti, тампонь іодоформной марли положень въ маточный рукавъ. Обцее состояніе больной xорошіо.

На другой день удаленъ тампонъ и положенъ новый изъ іодоформной марли. Температура больной нормальная. Матка плотно скратилась, кровотеченія нъ̈ть. Больной назначено. желъззо и хорошее питаніе. Чрезъ 5 мъс. явилась произвольная menstrua. До сегодня (2 годь и 5 мв̈сяс.) больная совершенно здорова. 